\title{
Sid \\ First report of a 16Srl-B subgroup-related phytoplasma associated with Eruca sativa phyllody in Iran
}

\author{
S.A. Esmailzadeh Hosseini ${ }^{1} *$ M. Salehi $^{2}$ and E. Salehi ${ }^{2}$ \\ ${ }^{1}$ Plant Protection Research Department, Yazd Agricultural and Natural Resources Research and Education Centre, AREEO, \\ Yazd, PO Box 89195-3165, Iran; ${ }^{2}$ Plant Protection Research Department, Fars Agricultural and Natural Resources Research \\ and Education Centre, AREEO, Zarghan, Iran
}

*E-mail: saesmailzadeh@iripp.ir

Received: 03 Oct 2015. Published: 21 Nov 2015. Keywords: Yazd province, virescence

During a 2012-14 survey for phytoplasma diseases, Eruca sativa phyllody (ESP) disease was observed in Abarkooh (Yazd province, Iran). Infected plants showed crown proliferation, witches' broom, little leaf, flower virescence, phyllody, sterility and stunting (Fig. 1). Total DNA was extracted from $0.2 \mathrm{~g}$ of fresh leaves and flowers from both infected and symptomless plants (Zhang et al., 1998). DNA samples were tested for phytoplasma by direct PCR using primer pair P1/P7 (Deng \& Hiruki, 1991; Schneider et al., 1995) and nested PCR using primer pairs P1/P7 and R16F2n/R16R2 (Gundersen \& Lee, 1996). Primer pair P1/P7 amplifies an $1.8 \mathrm{~kb}$ fragment of the phytoplasma ribosomal RNA operon which includes the 16S rRNA gene, the 16S-23S intergenic spacer region and a portion of the $5^{\prime}$ region of the $23 \mathrm{~S}$ rRNA gene. The R16F2n/R16R2 primer pair amplifies approximately $1.25 \mathrm{~kb}$ of the phytoplasma $16 \mathrm{~S}$ rRNA gene. PCR amplicons of $\sim 1.8$ and $\sim 1.25 \mathrm{~kb}$ respectively were obtained from all 10 of the phyllody-affected E. sativa (two per location) but not from symptomless plants. Five R16F2n/R16R2 amplicons from Esfandabad, Harooni, Bedaf, Taqhiabad and Mehrdasht locations were directly sequenced and showed $100 \%$ sequence identity to each other. A consensus sequence corresponding to the Aliabad-e Shams (Esfandabad, Abarkooh, Yazd province) E. sativa phyllody (AESP) phytoplasma was deposited in GenBank (Accession No. KT626568). A BLAST search showed that the AESP phytoplasma had $100 \%$ sequence identity with those of the $16 \mathrm{SrI}$ 'Candidatus Phytoplasma asteris' group (Aster Yellows group), including the onion yellows phytoplasma mild strain (OY-M) (NC_005303) representative of the 16SrIB subgroup. Phylogenetic analysis (MEGA software version 6.0) confirmed that the AESP phytoplasma clustered within the 16SrI phytoplasma clade (Fig. 2) closer to the 16SrI-B strains, OY-M and 'Ca. P. asteris' (M30790). Computer-simulated restriction analysis (Fig. 3) with 17 restriction endonucleases using $i$ PhyClassifier (Zhao et al., 2009) revealed that virtual RFLP patterns of the AESP phytoplasma were identical (similarity coefficient 1.00) to those of OY-M. This is the first report of a 16SrI-B phytoplasma associated with ESP disease in Iran. A 16 SrI-B related

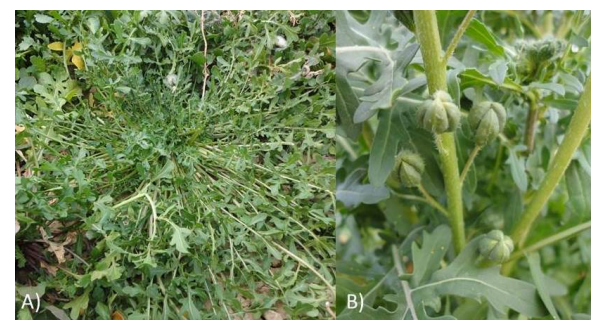

Figure 1

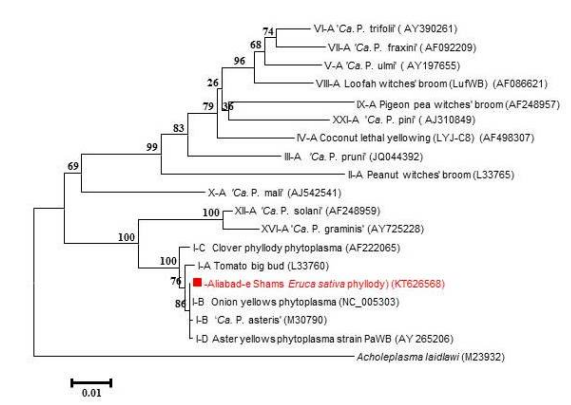

Figure 2 phytoplasma has been reported associated with rapeseed (Brassica rapa) phyllody in Iran (Salehi et al., 2011). Eruca sativa may be a secondary host for the 16 SrI-B phytoplasma associated with rapeseed phyllody.

\section{References}

Deng S, Hiruki C, 1991. Amplification of 16S rRNA genes from culturable and non-culturable mollicutes. Journal of Microbiological Methods 14, 53-61. http://dx.doi.org/10.1016/0167-7012(91)90007-D

Gundersen DE, Lee IM, 1996. Ultrasensitive detection of phytoplasmas by nested-PCR assays using two universal primer sets. Phytopathologia Mediterranea 35, 144-151

Salehi M, Izadpanah K, Siampour M, 2011. Occurrence, molecular characterization and vector transmission of a phytoplasma associated with rapeseed phyllody in Iran. Journal of Phytopathology 159, 100-105. http://dx.doi.org/10.1111/j.1439-0434.2010.01731.x

Schneider B, Seemüller E, Smart CD, Kirkpatrick BC, 1995. Phylogenetic classification of plant pathogenic mycoplasma-like organisms or phytoplasmas. In: Razin S, Tully JG, eds. Molecular and Diagnostic Procedures in Mycoplasmology, Vol. 1. Academic Press, San Diego, CA, USA, 369-380. http://dx.doi.org/10.1016/B978-012583805-4/50040-6

Zhang YP, Uyemoto JK, Kirkpatrick BC, 1998. A small-scale procedure for extracting nucleic acids from woody plants infected with various phytoplasmas for PCR assay. Journal of Virological Methods 71, 145-50. http://dx.doi.org/10.1016/S0166-0934(97)00190-0

Zhao Y, Wei W, Lee IM, Shao J, Suo X, Davis RE, 2009. Construction of an interactive online phytoplasma classification tool, $i$ PhyClassifier, and its application in analysis of the peach X-disease phytoplasma group (16SrIII). International Journal of Systematic and Evolutionary Microbiology 59, 2582-2593. http://dx.doi.org/10.1099/ijs.0.010249-0

To cite this report: Esmailzadeh Hosseini SA, Salehi M, Salehi E, 2015. First report of a 16Srl-B subgroup-related phytoplasma associated with Eruca sativa phyllody in Iran. New Disease Reports 32, 22. http://dx.doi.org/10.5197/j.2044-0588.2015.032.022 